\title{
TRANSLATION STUDIES AND BLACK DIASPORA STUDIES: A BRAZILIAN ITINERARY
}

\section{ESTUDOS DA TRADUÇÃO E ESTUDOS DE DIÁSPORA NEGRA: UM ITINERÁRIO BRASILEIRO}

\author{
Dennys Silva-Reis \\ Universidade de Brasília \\ Brasília, Distrito Federal, Brasil \\ Cibele de Guadalupe Sousa Araújo \\ Secretaria Municipal de Educação de Goiânia \\ Goiânia, Goiás, Brasil
}

\begin{abstract}
Diaspora Studies are an emerging area in Brazilian Academy, with different approaches both in the Social Sciences and in the Humanities knowledge fields. Concerning the Translation Studies, a timid but representative movement has emerged in the past years. However, it is still somehow dispersed and lacks a unitary and regulatory characteristic. Within this context, this paper approaches the complex relations between the Translation Studies and the Black Diaspora Studies, proposing a Brazilian itinerary of theoretical principles to think about the translation of Black diasporic texts. For this reason, the current situation of the Black ethno-social question in Brazil and the manner in which it occurs throughout the translation act are resumed. It is argued that both the engaged and the non-engaged translators, Black or White, are relevant within the context of the internationalization of texts of interest for the Brazilian Black populations. Thus, the importance of the delimitation of the field of Translation and Black Diasporas to the Translation Studies is emphasized.
\end{abstract}

KEYWORDS: Translation Studies; Black Diasporas; Black Textualities; Diaspora Studies; Black Population

RESUMO: Os estudos da Diáspora estão cada vez mais intensos no meio acadêmico brasileiro com abordagens singulares tanto nos domínios das ciências sociais quanto das ciências humanas. No que tange aos Estudos de Tradução, um movimento tímido, mas bem representativo tem surgido nos últimos anos de maneira ainda dispersa e sem uma característica unitária e reguladora. Logo, o presente artigo aborda as complexas relações entre os Estudos da Tradução e os Estudos da Diáspora Negra, propondo um itinerário brasileiro de princípios teóricos 
para se pensar a tradução de textos diaspóricos negros. Com esse objetivo se retoma a atualidade da questão etino-social negra no Brasil e como esta se dá no ato da tradução; defende-se a importância tanto de tradutores engajados ou não, brancos ou negros na internacionalização de textos de interesse das populações negras brasileiras; e argumenta-se a importância e a delimitação do campo Tradução e Diásporas Negras para $\mathrm{a}$ área Estudos da Tradução.

PALAVRAS-CHAVE: Estudos da Tradução; Diásporas Negras, Textualidades Negras; Estudos da Diáspora, População Negra 


\section{AN INTRODUCTION TO BLACK DIASPORA}

The word diaspora (from Classic Greek $\delta 1 \alpha \sigma \pi \mathrm{o} \rho \alpha$, "dispersion") was used, at first, to designate the involuntary dispersion of peoples that resisted assimilation or that were prevented of doing so. Therefore, originally, there were the Jewish, the Greek and the Armenian diasporas. With the development of Diaspora Studies, the word gained new meanings, through the addition of the generalist idea of referring to any kind of dispersion - forced or voluntary, assimilative or dissimilative, racial or national and even gender related ${ }^{1}$.

It was from this terminological point of view that Afro-American scholars started to name as "diaspora" the History of African descendants dispersed for different reasons (such as the exile, the migration, the expatriation, the nomadism, etc.), in the most diverse places (like the United States, Brazil, Cuba, Haiti, Costa Rica, to name a few). The American historian Linda Heywood (2015) states that the studies of the Black diaspora, in their origin, were interested, particularly, in the investigation of the slavery system developed by Europe and put into practice in America, Asia and Oceania. Researches related to Black diaspora brought, among other concepts, the notions of "South Atlantic System", "Black Atlantic" and "Atlantic World". These notions have, somehow, revitalized multiple dimensions of analysis of the African diaspora, especially in relation to its cultural domain.

According to the Brazilian researcher Nei Lopes:

[a] Diáspora Africana compreende dois momentos principais. O primeiro, gerado pelo comércio de escravos, ocasionou a dispersão de povos africanos tanto pelo Atlântico quanto pelo oceano Índico e mar Vermelho, caracterizando um verdadeiro genocídio, a partir do século XV - quando talvez mais de 10 milhões de indivíduos foram levados, por traficantes europeus, principalmente para as Américas. O segundo momento ocorre a partir do século XX, com a emigração, sobretudo para a Europa, em direção às antigas metrópoles coloniais. ${ }^{2}$ (2011, p. 51)

Beyond acknowledging the effect of the African Diaspora, it is noticeable, nowadays, that another preoccupation is strongly emerging: the homogenization of the adjective "African". The origin of this fact goes back to the movement called "Pan-Africanism", inside which the search for solidarity and union around

\footnotetext{
${ }^{1}$ For further understanding, the works of KhachigTölölyan $(2014,2007,1996)$ and Rogers Brubaker (2005) are indicated.

${ }^{2}$ [the] African Diaspora comprises two main moments. The first one, generated by the slave trading, propitiated the dispersion of the African peoples through the Atlantic, the Indic Ocean and the Red Sea, characterizing a true genocide, from $15^{\text {th }}$ Century XV when maybe over 10 million individuals were taken, by European traders, mainly to the Americas. The second moment occurs from the $20^{\text {th }}$ Century on, with the emigration, mostly to Europe, heading to the old colonial metropolis (our translation).
} 
all African countries was promoted (EDWARDS, 2001). This movement pursued a cultural, discursive and social unity among all African individuals.

On the one hand, the movement marked its difference in relation to the other continents in various domains of the human experience. On the other hand, it fairly helped to spread and, sometimes, even to deepen cultural and social stereotypes. This paradox contributed, in part, to the fact that the movement did not last long. Nonetheless, homogenizing ideas of African culture and society cannot be sustained anymore. Countless scholars, from diverse knowledge fields, agree that it is no longer possible to talk about the African diaspora (in the singular form). Instead, the discussion should take place around African diasporas (in the plural form).

If one looks back at the Brazilian History, it is known that the Africans who were enslaved here came from different areas of that continent. Therefore, the religious orientations that they brought with them did not come from just one African religion, but from many of them. Even the African influences in Brazilian Portuguese language come not only from just one African language, but, at least, from two different linguistic families. Consequently, the concept of Black Atlantic culture cannot and should not be unique, closed or centered in just one ideal of Africanity, since there are cultural remnants that linger in the form of History, memory and archive, but that, despite their permanency, are, constantly, in transit, being transformed and transculturated.

The American researcher Hortense Spillers (2003) states that the Afrocentric ideal imposes a distance between the allegedly African Diasporic culture and the other African cultures. For Spillers, there is a fictitious unidimensional and invented man who propagates an imagined culture, which, somehow, folklorizes the idea of Africa as something syncretic, universal and unidifferential. Within this context, there would be a trend of technocritization of the thought and of the culture to "facilitate" the African Diaspora idea. However, this homogenizing action is a way to dehumanize culturally and socially the understanding of the African diversity and of the African Diasporas hybridism. Furthermore, the acknowledgment of the processes of cultural hybridism would no longer lead to a unique African Diaspora, but to the formation of Black cultures and of Afro-diasporic cultures.

In the acceptance and celebration of difference, it should be highlighted that they are only possible because of the presence of subjectivity. According to Professor Khachig Tölölyan (2014), the existence of diasporas becomes potential only when there is the "cult" of memory, usually traumatic, and, alongside this, the rescue of the homeland, a sort of ethnic identity. These two subjectivities are transformed according to the bicultural competence, through which the diasporic communities select the elements from which they can be proud of their ancestral culture, but, at the same time, they do not fully acknowledge a diasporic identity that goes against their national and moral principles and that lead them to fit in behaviors they do not agree with nor wish to adopt. That means that the diasporic communities assemble the local and the home creating, consequently, hybrid multiple identities. Probably, that is the reason why it is possible to talk about Black diasporas and not only about African diasporas. 
The Black traumatic memory is perennial and other daily facts are added to it, making, in such way, a type of resistance discourse, an aesthetic strength and an identity common core, even if such diaspora have local colors. The idea of Black diasporas seems to be more embracing, because it belongs to the African diaspora, but also to new emerging diasporas, such as the Haitian, the Cuban, the Brazilian, the Antillean, among others. Thus, in contemporaneity, as in other historical moments, there is a tendency to attempt the reconstruction of a Black imagined territory. Such territory would enable the search for recognition and belonging, without, however, falling into existentialism. This Black imagined community increasingly delimits its territory with Black bodies occupying places never previously imagined, with sharper discourses and marked aesthetics, above all, for its singularity and no longer for the dichotomy difference/comparison; in short, by the utterance and presentification of Black voices.

This set of presentificational actions, which has been progressively intensified, was created firstly by the rise of the consciousness of color, followed by the consciousness of race and, at last, a few years ago, it has been centered around the question: What is this 'black' in Black Culture/Diaspora? (HALL, 1992; GILROY, 2000; STEPHENS, 2009). Thus, by itself, the epidermal thinking or the epidermization, in the terms of Paul Gilroy (2000), would not be capable of answering the question of what "the black" in Black Diaspora is or else to explain in what consists its superiority or inferiority within the outdated limits of the concept of race.

Two remarks can be emphasized here: the first one is that it is only possible to identify oneself as Black in relation to the White; and the second one is that independently of where the Black individual is, he/she will be identified as Black. These two observations, already pointed out in the works of Frantz Fanon (2008), in the past century, that accompany the Black diasporas, bring light to its major characteristic: the existence of an intercultural and transnational relation, that is, the existence of a Black psyche.

The Black psyche, that is, the collective unconsciousness of the Black community, is historically rooted and became stronger as it confronted the colonialism. Moreover, it tends to intensely articulate itself to the social changes of each country and to the global political economic conditions for the Black population. And it is from this deep perspective that one can approach Black diasporas. The inter-subjectivation of the Black being in each member of the Black communities tends to influence the pursue of a Black interpersonal intercultural identity dimension that, as a result, aims at a vision of the world and at unique particular strategies of experience (STEPHENS, 2009).

\section{TRANSLATION AND BLACK DIASPORA}

As discussed in the previous section, the delimitation of the Black territory has been markedly local. However, these local facts, acts and discourses have been travelling and have also been re-appropriated by other local Black 
communities through inspiration, imitation or aesthetic, political and social continuity. According to Brent Hayes Edwards (2003), there has been an internationalization of black culture, which intensively contributes to its diasporas. Within this context, two of the instruments of the practice of the Black diasporas would be, undoubtfully, the translation - be it a product, be it a process - and its cultural agent, the translator - be him/her White, be him/her Black.

Edwards $\left(2003^{3}\right)$ calls attention to the fact that great part of the Black population cannot speak a foreign language, for the most diverse reasons, including historic ones. It should be highlighted here that such ability is related, most of times, to the formal linguistic variation of languages of hegemonic representative cultures, not comprising a substantial variety of countries with a bior plurilingual Black population, as in many African countries, in which, because of a forced populational organization imposed by the colonial endeavor, many ethnicities, with different languages, were enclosed within a single country.

Furthermore, Black discourses travel and the way they are translated, disseminated, reformulated and debated in the transnational contexts is primordial, since the first claim to be made is that these texts form individual, collective and institutional archives of Black cultures. It must be emphasized here that archive, as defined by Michel Foucault, is the "general system of formation and transformation of statements" (1972, p. 130). In accordance to this author:

[b]etween the language (langue) that defines the system of constructing possible sentences, and the corpus that passively collects the words that are spoken, the archive defines a particular level: that of a practice that causes a multiplicity of statements to emerge as so many regular events, as so many things to be dealt with and manipulated (FOUCAULT, 1972, p. 130).

In consonance with Foucault, there is a general discourse system in which the statements are deposited, revisited and stratified. It is this system that guide the appearing of new statements e their accumulation, as well as their history, their forgetfulness and their disappearing. It is likely that this could also be the system that rules the translation world, be it as linguistic economics, be it as horizon widening. The French philosopher also states that:

\footnotetext{
${ }^{3}$ In the original text, the author refers exclusively to the American Black population. However, the situation in Brazil does not seem to be different.
} 
[t]he description of the archive deploys its possibilities (and the mastery of its possibilities) on the basis of the very discourses that have just ceased to be ours; its threshold of existence is established by the discontinuity that separates us from what we can no longer say, and from that which falls outside our discursive practice; it begins with the outside of our own language (langage); its locus is the gap between our own discursive practices. In this sense, it is valid for our diagnosis. Not because it would enable us to draw up a table of our distinctive features, and to sketch out in advance the face that we will have in the future. But it deprives us of our continuities; it dissipates that temporal identity in which we are pleased to look at ourselves when we wish to exorcise the discontinuities of history; it breaks the thread of transcendental teleologies; and where anthropological thought once questioned man's being or subjectivity, it now bursts open the other, and the outside. In this sense, the diagnosis does not establish the fact of our identity by the play of distinctions. It establishes that we are difference, that our reason is the difference of discourses, our history the difference of times, our selves the difference of masks. That difference, far from being the forgotten and recovered origin, is this dispersion that we are and make. (FOUCAULT, 1972, p. 130-131).

In other words, once it is admitted that the system of statements of a certain community or culture can be progressively strengthened or weakened through different discursive practices derived from heterogeneous places, the existence, the acquaintanceship and the dispersion of and with the Other are established, because it is admitted that there are other ways of thinking and being - personally, institutionally and collectively. The translation is one of these discursive practices with particular function of multiplying a preexisting system of archives in a certain community or culture, since, beyond crossing the linguistic bridge from one side to another, it enlarges and introduces new statements, ways of thinking and being. Therefore, it constitutes an important diasporic instrument. More than linguistic connections, through translation, cultural connections, alliances of ideas and practices, international interactions and welcoming are made.

According to Edwards (2003), the translation within the Black diaspora realm is a process of articulation, in which there is difference within unity. Therefore, in translation, there is a remainder of the source text and there is, equally, a clear temporal and spatial difference, there is a décalage, in Edwards's point of view, since translation is always and inevitably a post-scriptum. However, once a text is translated and belongs to the Black diaspora, it is likely that it will bind itself to its receptors, by reactivating the unconscious archive of the diaspora it belongs to. Under this light, the translation, besides being an instrument, mediates and spreads the Black diasporic cultures. And the translator, consequently, is the agent of such a process, the host of the welcoming of the Other. 
Such orientation given to the translator is in agreement with what the Brazilian scholar Solange Mittmann called the translator function, which is:

[a] função tradutor é responsável pela organização das vozes presentes no processo tradutório, bem como pelo direcionamento de uma interpretação, criando a ilusão da homogeneidade e da transparência. É responsável pela ilusão de que o tradutor, como sujeito enunciador, é dotado de unidade, coerência e responsabilidade sobre seu dizer, resgatando e reproduzindo os sentidos do original (MITTMANN, 2003, p. 136). ${ }^{4}$

Therefore, once a Black translation culture is created and a Black diasporic identity translation is made, besides the professional aspect and the linguistic work itself, there is an ethical and political aspect - a social and conscious responsibility over his/her saying-making - that can excel as the greater movement of the translation act. In the words of the Brazilian researcher Denise Carrascosa:

[a] tarefa tradutória, nesse sentido ético-político, processa-se em um doublebind que agencia, ao mesmo tempo, a) o sujeito da tradução em sua relação erótica com o texto a traduzir, relação de amor em que o texto literário constitui dimensão de sua própria intimidade e b) a abertura do eu para o outro da cultura, através da linguagem, dimensão coletiva com a qual o tradutor produzirá uma comunidade por vir. Essas duas instâncias fazem acoplar-se o privado e o público de forma a fazer funcionar o dentro e o fora do sujeito tradutor a partir de uma dobradiça que me interessa pensar como "função-tradutor". Para definir a "função-tradutor", é preciso, em primeira instância, operar por exclusão (duas negações): 1) não representa univocamente uma atividade criativa e/ou profissional; b) não encontra correspondente em um sujeito que realiza esta atividade ${ }^{5}$. (2017, p. 68-69)

\footnotetext{
${ }^{4}$ [the] translator function is responsible for the organization of the voices involved in the translation process, as well as for the directing of an interpretation, creating the illusion of homogeneity and transparency. It is responsible for the illusion that the translator, as an enunciator subject, is gifted with unity, coherence and responsibility over his/her saying, rescuing and reproducing the original meanings (MITTMANN, 2003, p. 136) (our translation).

${ }^{5}$ [t] he translation task, in this ethical-political sense, is processed in a double bind that activates, at the same time, a) the subject of the translation in relation to his/her erotic relation with the text to be translated, loving relation in which the literary text constitutes a dimension of the very intimacy and b) the openness of the self to the other of the culture, through language, collective dimension with which the translator will produce a future community. These two instances assemble the private and the public in a way that puts to function the inside and the outside of the translator subject through a hinge that suits me to think of as the "translator-function". To define the "translator-function", it is necessary, firstly, to operate by exclusion (two negations): 1) it does not represent solely
} 
Carrascosa, like Mittmann (2003), borrows the Foucauldian theoretical apparatus of the author-function while defining the translator-function. The author-function is a way of characterizing the different discourses, where they are produced and what affects their circulation and functioning (FOUCAULT, 2013). Once the translator chooses this way of being of the discourses, with a conscious and engaged attitude, he/she extends his/her function beyond the work expected. There is not only a linguist-cultural displacement anymore, but an ethical-political translating is added to such displacement. The translator becomes, as a result, a loving co-author. He/she appropriates the text in a singular manner, reassures his/her personal discourse in the reliability of the text being translated, rationalizes in the company of the author materialized in the text, writes his/hers (personal and professional) "selves" along with the "selves" of the author. The translation process becomes an act of double escrevivência ${ }^{6}$, through the articulation of the translator's personal experience with the source text (the first escrevivência). Therefore, Carrascosa defends that:

[p]ara que alguém se possa investir nessa tarefa intensamente mobilizadora, não é difícil entender que precise estar fortemente afetado pelo vetor de força da afrodiasporicidade em sua experiência subjetiva; seja em seu próprio corpo, que carrega nas cores e nos traços a forma e a força da negritude; seja em seu desejo de uma experiência ética do social, que passe necessariamente pelo diálogo amoroso com um "eu" da cultura que se apresenta como força constitutiva de seu próprio outro.

[...] A função-tradutor - o mecanismo de funcionamento de produção de discursos em desvio e diferença - pensada como força capaz de curar/envenenar as relações de força agenciadas pelos regimes de signos violentamente subalternizantes (nesta discussão, o racismo etnocida) - pode ser compreendida como agência de sujeitos que, por força de sua intimidade com a dor e a potência subversiva que tais regimes engendram, movimentam um repertório de traços afrodiaspóricos e se deixam afetar amorosamente pelas vozes e textualidades de escritoras e escritores do Atlântico Negro.

a creative and/or professional activity; 2) it does not have a correspondent in a subject that performs this activity (our translation).

${ }^{6}$ This expression was created by the Brazilian Black writer ConceiçãoEvaristo to designate her authorial form of writing. The neologism blends the Portuguese words "escrita/escrever" and "vivência". In English, a parallel neologism would blend the words "writing" and "experience", resulting in something like: "writinsperience". 
Seu exercício tradutório não configura apenas um trabalho instrumental comunicativo de ampliar a acessibilidade e o diálogo entre escrita e leitura nesse outro espaço-tempo imaginado; mas, suplementarmente, produz uma performatividade na linguagem capaz de deslocar, descentrar e rearticular possibilidades de sentidos reversores das forças etnoepistemicidas. Seu trabalho tradutório configura-se como exercício de uma performance de si, a partir da qual emergem subjetividades transformadas e transformadoras, ciosas de uma construção identitária ética em sua relação a si e sua abertura amorosa para a alteridade (CARRASCOSA, 2017, p. 72-73) ${ }^{7}$

Aggregating another way of defining the translator-function, it is also possible to identify the critique of the diasporic translation as another form of translator-function ${ }^{8}$, as, a priori, in order to criticize there has to be an empathy with the first escrevivencia (the source text), besides the linguistic knowledge which, while comparing translation and original texts, articulates in itself a third text not materialized in the translation, but with translation properties and exposed in a critical layout. This position justifies the increasing number of academic researches about the Black translation diaspora, because the translation critique is another form of welcoming the difference and the Other of Black cultures, in addition to signaling the success or failure of such welcoming.

Considering all the discussions above, one question remains: is it possible to contribute to the Black diasporas through translation without fitting in the

\footnotetext{
${ }^{7}$ [i] $\mathrm{n}$ order to dedicate oneself to this intensively mobilizing task, it is not difficult to understand that one should be deeply affected by the Afrodiasporicity power vector in one's own subjective experience; be it in one's own body, that carries in its colors and traces the form and the power of the negritude; be it in the desire of an ethical experience of the social that necessarily passes through the loving dialogue with a "self" of the culture that presents itself as a constitutive power of its own other. [...] The translator-function - the mechanism of functioning of the production of discourses in defiance and difference - thought of with the power capable of healing/poisoning the power relations mobilized by the regimes of signs violently subalternizing (within this discussion, the ethnocide racism) - can be understood as agency of subjects that, by the power of their intimacy with the pain and the subversive potential that such regimes generate, put into movement a repertoire of Afrodiasporic traces and allow the voices and textualities of writers from the Black Atlantic to lovingly affect them. The translation task does not constitute a sole instrumental communicative work of enlarging the accessibility and the dialogue between writing and reading within the imagined space-time; but, as a supplement, produces a performativity in the language capable of displace, decenter and rearticulate possibilities of reversal senses of the ethnoepistemicide powers. The translation work constitutes itself as an exercise of performance in itself, through which emerge transformed and transforming subjectivities, conscientious of the construction of an ethical identity in its relation with itself and its loving openness to otherness.

${ }^{8}$ An example of translator-function from the ethical-political point of view could be the work done by Tobias Barreto concerning the implementation of the Germanism in Brazil (our translation).
} 
translator-function? The answer is positive. Once translating diasporic textualities, even without an ethical-political identity, the text can (or cannot) affect the translator and, moreover, the essential principles of the translation act (namely: the verbal principle, the representational principle and the performative principle) are activated. These principles underlie every single translation, both as process and as product. And even though sometimes epistemologies may be subverted during the translation process, diasporic remainders can still be identified. These, for their own turn, can (or cannot) be added to/ by the local Black diasporic communities.

\section{TRANSLATION PRINCIPLES IN BLACK DIASPORA}

The translation verbal principle is mostly articulated to the transmission of the message, that is, to the discourse transposition in which it is possible to transfer topics, ideas, narratives and statements about the Black cultures to another culture (Black or not). It is the foundation of the translation and the raw material of the translator. For his/her own turn, the translator, imbued by the remnant of the textual-discursive neutrality and invisibility, imposed by an allegedly translation fluency, in addition to the impositions of the translation market system (such as limited time lapse for the translation work, editorial norms, obligations of the relation between client and translator, etc.), plays his/her role as a sheer decoding channel for the message - as if it were possible! Nevertheless, even a "mechanical" translation action opens opportunity to the transit of Black diasporic cultural elements, be it through the enrichment of the language, be it through the rhetoric or style of the text, be it as knowledge dissemination.

As an example of that, the work Amkoullel, o meninofula, by Amadou Hampâté Bá, translated in Brazil, in 2013, by Xina Smith de Vasconcellos, can be taken into consideration. This specific translation, besides conveying knowledge about Africa, was made to emphasize the rhetoric and the style of its author, a great African short story writer from the oral tradition of the griots. Whether Vasconcellos had any level of engagement and appreciation for the source text or not, it is undeniable that the translator's work resulted in a great contribution for the Malian Black culture sharing among the Brazilian audience. Beyond the literary writings, there is the example of the translation of textual genres within the religious or gastronomical spheres of African origin texts. When translated into Brazilian Portuguese, such texts bring the knowledge of those spheres, enriching, at the same time, the target language as they are culturally marked texts filled with particular vocabulary items from Black-African communities.

The representational principle, for its turn, is deeply related to the question of the identity (de)formation, enlargement or restriction, as well as to the question of the projection of horizons of expectation and of shared values among cultures. Thus, the translated text is a form of re-imagination of the Other (AMORIM, 2015) and, once playing the role of translator, it is virtually impossible not to 
enter such path. That happens because the translator, as the subjective being he/she is, is also impregnated with the personal values or universal sayings of his/her culture, even when they are not effectively aware of that.

Besides taking into consideration those components, another element should be considered: the space of experience, a concept coined by the German historian Reinhart Koselleck (2004). Both the translation-process and the translation-product are spaces to experience the Other. The translator, before the reader, is the first person to be in such space of experience. The reader, while reading the translation - that also offers a space of experience -, does not have access to the same space of experience experienced by the translator, since the reader's space will be more hybrid, as the space of experience of the text is assembled with the experience of the translator. It is worth recalling here what does experience mean:

[t]he experience is present past, whose events have been incorporated and can be remembered. Within experience a rational reworking is included, together with unconscious modes of conduct which do not have to be present in awareness. There, is also an element of alien experience contained and preserved in experience conveyed by generations or institutions (KOSELLECK, 2004, p. 359).

In other words, regarding translation, a prior text (past) is reformulated into a current text (present). In the current text, the translation, the rational form (the linguist materiality) and the subjective forms of a possible collective unconsciousness of the language of the source culture are recalled and merged, that results in the preservation and in the inclusion of the difference, of the Other, in the new linguistic materiality. In this perspective, it is possible to state that even if the translator is not ethically or politically engaged his/her translation can represent a discursive Other, a cultural Other. Concerning Black culture, the fact that a work has been translated in Brazil in a non-engaged way or with no loving attitude by the translator does not necessarily mean that it will not introduce nor represent the Other.

One of the most interesting examples of that is the case of the translator Cid Knipel Moreira. Two foundational texts of Black culture were translated by him: the essay The Black Atlantic: Modernity and Double-Consciousness $(O$ Atlântico Negro: Modernidade e Dupla consciência - translated in 2012), by Paul Gilroy, and novel Black Mischief (Malícia Negra - translated in 2003), by Evelyn Waugh. As far as it is known, this translator does not have or defend an ethicalpolitical project as a professional, concerning the question of Black cultures and diasporas. However, his translations are respected (there is not any criticism available about his translation, concerning the comparison of the languages and cultures) and valued as great contributions to (and by) the Brazilian Black community. How does one explain that? Probably, the translator introduced the Other unconsciously, offered the space of experience of such Other to the reader and reimagined, somehow, this Other to the probable audience of these texts. It is possible that the cultures of both books have contributed to the success of these 
translations. Nevertheless, the success of the text in Brazilian Portuguese is accounted to the translator who, somehow, brought such discursive representation and representativeness to the Brazilian audience.

The third essential principle of the translation act is the performative one. A translation is an event both from the point of view of its production, since there are choices to be made in order to bring translation into the world, and from the point of view of the reception, or the audience, since a response from the translation receiver is identifiable accordingly to the translator's choices and to the instances that accompany him/her. Lenita Esteves (2014) believes that translation is a performative act and, as such, it produces effects on the target culture. These effects might be the most diverse, like: knowledge diffusion, immersion on the textuality, enrichment, political intervention, among others.

It is possible that the reason that best justifies the translation as a performative act might be the fact that in it there will always be a continuous creation, a sort of mouvence, in the words of Zumthor (2005). A mobility of sign that never depletes itself, but that is always continuous and re-contextualized. On the one hand, the verbal performativity can be explained by the muting context both cultural and temporal -, that is where the probable explanation for the retranslations comes from. On the other hand, every translation is linked to language doings that are external to the linguistic materiality. Therefore, what the words make inside and outside the text does not depend only on the author, the translator or the reader, but also on their situation, on their context (CARLSON, 2009). Within the performative question of the text under translation, there are the inferences, the intentionality and the actual effect that such translation can reach, besides, of course, the judgment of an observer that, with some authority, can say if the performativity of the translation succeeded or not. That means every translator, apart the (in)existence of engagement, as well as the translationproduct is inserted in a context.

In relation to the Black diasporas in Brazil, the matter of affirmative actions, such as racial quotas, the law that grants the inclusion of the study of African cultures in schools and the controversial arguments about the Black question in the many areas and instances of society are raising a context - even with a great deal of confrontation and battles - increasingly propitious to a deeper acceptance and connection of the Black culture. Not by mere coincidence, there is a noticeable non-engaged movement of many non-academic publishing houses introducing Black authors, through translation, in the Brazilian literary system. Such a movement is described on the chart below. 


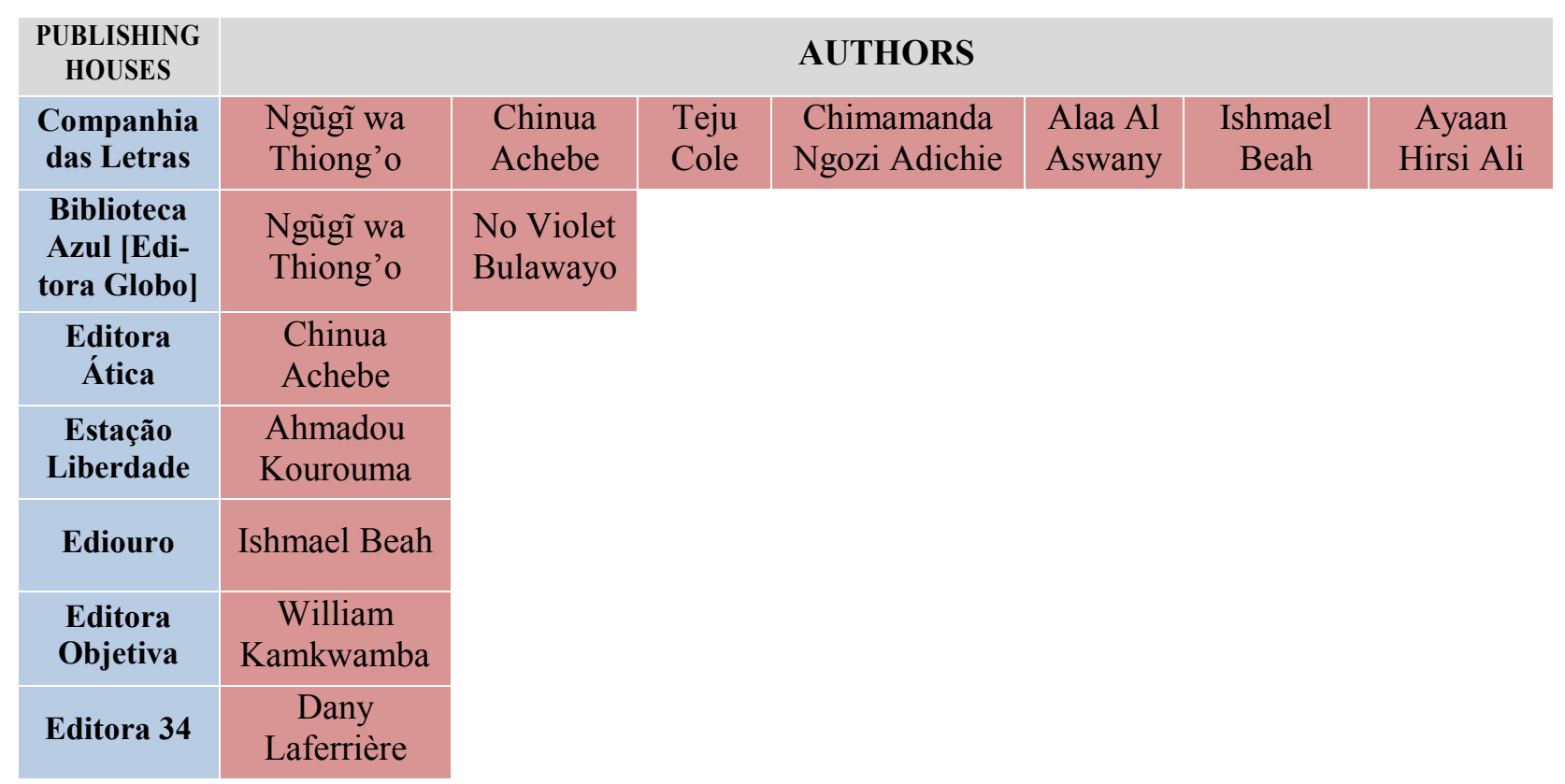

Table 1: Black authors published in Brazil. Source: Publisher sites

It should be highlighted that all these authors had their works translated into Brazilian Portuguese only after they were internationally acclaimed. Nonetheless, even if that was the criteria of the publishing houses, the prevalence of hegemonic cultures and of the Black non-representativeness is being replaced by the presence of Black cultures. That is the reason it can be stated that both the non-engaged translator and translation can still offer a contribution to the local Black culture. In addition to these facts, it should be mentioned that, within the performative principle of the translation, events (such as parties, spectacles, celebrations, solemnities, etc.) can both boost and disclose translation, as in the case of FLIP (The International Literary Party of Paraty), which, in 2017, invited the Rwandan writer Scholastique Mukasonga. Her presence at the event inspired the Brazilian publishing house Editora Nós ${ }^{9}$ to translate two of her works into Brazilian Portuguese.

\section{ENDING OR BEGINNING? A NEW DOMAIN OF THE TRANSLATION STUDIES IN BRAZIL}

Both the translation practice and the translation studies within Black diasporas contexts have become an emerging field inside the area entitled Translation Studies in Brazilian territory. On the one hand, such an area of studies has been able to give discursive and representational opportunity and acknowledgment. On the other hand, the search for a praxis that comprehends this specificity - for the translation of texts from and/or that approaches Black

\footnotetext{
${ }^{9}$ More detailed information available at: $<$ http://editoranos.com.br $>$. Accessed in 28 july 2017.
} 
diasporas do constitute a specificity, just as the translation of texts from scientific, economic, legal areas (among others), and that such specificity demands and deserves special attention by translators so that they address its characteristics and specifications of their textuality, their themes, their images, styles, contexts. In addition, the translation practice, in all its modalities in Brazil, within Black diasporic contexts has put the Black culture at issue, be it by acknowledging its absence, be it by mobilizing itself for a space for/and of the Black - and it is, within this context, that many social communities of Black textualities translation have arisen.

Although it has been argued that the lack of engagement does not implies a necessary lack of quality in the translation or even in the absence of a contribution to the local Black community and culture, it should be emphasized that there may be a conduction of the translation act and reception as a movement of assimilation, misrepresentation, stereotypization and caricaturization, both of the Back cultures and of Black people's image. Such movements, of assimilation and reduction (sometimes even racists!) seem to happen more frequently in other translation modalities or types, like the audiovisual translation, the inter-semiotic translation and the versionism, to which few researches are dedicated, in the Brazilian fields of Translation and Black Diasporas.

In addition to this scenario, the interpretation is an almost impenetrable area for Black agents. The relations between Black culture and interpretation in Brazil are still obscure. There is a prejudice with the question of the Black as interpreter due to a supposedly whiteness status of the profession. Concerning the access to the profession, there are well prepared and skilled Black professionals. However, there is also a dominant racism ruling the relations between the professionals and the clients of such services. Besides, the relations of Black interpreters dealing with racial matters in the interpretation act bring light to other complex, contextual, psycholinguistic, emotional and historic elements, which are still barely approached academically.

It is a known fact the racism is not a Brazilian but a global problem and so are the complexity of the questions between translation and Black diasporas. Nevertheless, it seems that the Brazilian itinerary regarding the questions discussed in this paper can dialogue with other Geo-political itineraries of translation, giving strength to this domain that is "new", but, at the same time, current and necessary if one is to think about translation as an ethnic-ethical practice or even as one that respects and welcomes the Other.

\section{REFERENCES}

AMORIM, L. M.. "Tradução \& Identidade". In: AMORIM, Lauro M.; RODRIGUES, Cristina C.; STUPIELLO, Érica N. A.. Tradução \& perspectivas teóricas e práticas. São Paulo: UNESP Digital, 2015. 
BRUBAKER, Rogers. "The 'diaspora' diaspora”. In: Ethnic and Racial Studies, $28,2005$.

CARLSON, Marvin. Performance: uma introdução crítica. Translated by Thaïs Flores Nogueira and Maria Antonieta Pereira. Belo Horizonte: Editora UFMG, 2009.

CARRASCOSA, Denise. "Traduzindo no Atlântico Negro: por uma práxis teórico-política de tradução entre literaturas afrodiaspóricas". In:

Traduzindo no Atlântico Negro: Cartas Náuticas Afrodiásporícas para Travessias Literárias. Salvador - Bahia: Ogums Toques Negros, 2017.

EDWARDS, Brent Hayes. "The uses of Diaspora". Social Text 66 V. 19, N. 1, Primavera - 2001.

. The practice of diaspora: literature, translation, and the rise of black internationalism. Cambridge/Massachusetts/London: Harvard University Press, 2003.

ESTEVES, Lenita M. R.. Atos de tradução: éticas, intervenções, mediações. 1. ed. São Paulo: Humanitas/FAPESP, 2014.

FANON, Frantz. Pele Negra, Máscaras Brancas. Translated by Renato da Silveira. Salvador: EDUFBA, 2008.

FOUCAULT, Michel. The archaeology of Knowledge \& the discourse on language. Translated by M. Sheridan Smith. New York: Pantheon books, 1972.

FOUCAULT, Michel; MOTTA, Manuel Barros (Org.). Estética: Literatura e Pintura, Música e Cinema. Tradução Inês Autran Dourado Barbosa. 3 ed. Rio de Janeiro: Forense Universitária, 2013.

GILROY, Paul. Against Race: Imagining Political Culture beyond the Color Line. Cambridge: Harvard University Press, 2000.

HALL, Stuart. "What is this 'Black' in Black Popular Culture?". In: DENT, Gina (Org.) Black Popular Culture. Seattle: Bay, 1992.

HEYWOOD, Linda H. Diáspora negra no Brasil. Translated by Ingrind Castro Vompean Fregonez, Thaís Cristina Casson e Vera Lúcia Benedito. São Paulo: Contexto, 2015.

KOSELLECK, Reinhart. Futures Past: on the semantics of historical time. Translated and whit introduction by Keith Tribe. New York: Columbia University Press, 2004.

LOPES, Ney. Enciclopédia Brasileira da Diáspora Africana. São Paulo: Selo Negro, 2011. 
MITTMANN, Solange. Notas do tradutor e processo tradutório: análise e reflexão sob uma perspectiva discursiva. Porto Alegre: Ed. UFRGS, 2003.

SPILLERS, Hortense J.. "The Idea of Black Culture". CR: The New Centennial Review, V. 6, N. 3, Inverno - 2006.

STEPHENS, Michelle. "What's is this Black in Black Diaspora?". Small Axe. N. 29. V. 13, N. 2, 2009.

TÖLÖLYAN, Khacig. "Diaspora studies: Past, present and promise". Oxford Diasporas Programme. International Migration Institute (IMI), Oxford Department of International Development (QEH), University of Oxford, 2014. Available at $<$ https://www.imi.ox.ac.uk/publications/wp-55-12>. Accessed in 28 july 2017.

. "Rethinking diaspora(s): stateless power in the transnational moment". Diaspora: a journal of transnational studies, 5(1): 3-36, 1996.

. "The contemporary discourse of diaspora studies". Comparative Studies of South Asia, Africa and the Middle East 27(3): 647-55, 2007.

ZUMTHOR, Paul. Escritura e Nomadismo. Tradução Jerusa Pires Ferreira. São Paulo: Ateliê Editorial, 2005.

Dennys Silva-Reis

ReisDennys@gmail.com

Cibele de Guadalupe Sousa Araújo

Guadalupe.Sousa@gmail.com

Recebido em: 21/9/2017

Aceito em: 20/2/2018

Publicado em Abril de 2018 